\title{
PERMUKIMAN LIAR (SQUATTER SETTLEMENT) DI JALUR KERETA API KOTA SEMARANG
}

\author{
Mohammad Agung Ridlo \\ Dosen Program Studi Perencanaan Wilayah dan Kota, Fakultas Teknik, UNISSULA \\ Penulis Korespondensi E-mail: agungridlo@unissula.ac.id
}

\begin{abstract}
Squatter settlement is increasingly spreading in various urban corners of Indonesia, including in Semarang Metropolitan City. The reality of existing squatter settlements invaded vacant land, unpreserved and lacked (no) supervision from landowners, eventually forming slum enclaves, one of which was on the railway line in Semarang City. Railways should not be allowed to be used as residential areas. The squatter settlement is inhabited by people on low incomes (economically incapable). Research methods are conducted in a qualitative scriptive way, through empirical observation, interactively, with inductive methods. The approach of the room system is carried out to interpret circum citizen activity related to the request or zoning.Meanwhile, theoretical studies were conducted to help identify and analyze in this study. This research illustrates that squatter settlement occurs in addition to the retardation and poverty experienced by citizens, also due to the inability of the government and its apparatus in terms of supervision (Uncontrolled). Therefore, space arrangement is required (including planning, coaching, implementation, supervision and control).
\end{abstract}

Keywords: squatter settlement, railway

\begin{abstract}
ABSTRAK
Squatter settlement makin merebak di berbagai sudut perkotaan di Indonesia, termasuk di Kota Semarang Metropolitan. Realita yang ada squatter settlement merebak menginvasi lahan-lahan kosong, tidak terpelihara dan kurang (tidak ada) pengawasan dari pemilik lahan, akhirnya membentuk enclave-enclave kumuh, salah satunya di jalur kereta api di Kota Semarang. Jalur kereta api semestinya tidak diperkenankan untuk dijadikan sebagai kawasan permukiman. Squatter settlement tersebut dihuni oleh orang-orang yang berpenghasilan rendah (tidak mampu secara ekonomi). Metode Penelitian dilakukan secara diskriptif kualitatif, melalui observasi empirik, interaktif, dengan metoda induktif. Pendekatan sistem keruangan dilakukan untuk menginterpretasikan circum aktivitas warga kaitannya dengan permintakatan atau zoningnya. Sedangkan kajian teoritis dilakukan untuk membantu mengidentifikasi dan menganalisis dalam penelitian ini. Penelitian ini menggambarkan bahwa squatter settlement terjadi selain masih adanya keterbelakangan dan kemiskinan yang dialami oleh warga, juga dikarenakan ketidakmampuan pemerintah dan aparatnya dalam dalam hal pengawasan (Uncontrolled). Karenanya, diperlukan adanya penataan ruang (meliputi perencanaan, pembinaan, pelaksanaan, pengawasan dan pengendalian).
\end{abstract}

Kata Kunci: squatter settlement, jalur kereta api 
Jurnal Planologi Vol. 17 No. 2, Oktober 2020

Available : http://jurnal.unissula.ac.id/index.php/psa

\section{PENDAHULUAN}

\subsection{Latar Belakang}

Kota-kota di negara ini menghadapi paradoks perkembangan yang sering disebut dengan dualisme perkotaan atau kota berwajah ganda (Dieters, Hans Dan Rudiger Korff, 2002). Di satu sisi adanya percepatan pembangunan fisik dan ekonomi, maraknya gedung gedung pencakar langit, namun pada sisi lain di sudut sudut kota tampak permukiman kumuh yang berupa gubug-gubuk liar atau squatter settlement. Fenomena keberadaan squatter settlement terbentuk secara organik, sebagai bagian dari suatu permukiman kota yang merebak sejalan dengan perkembangan kota.

Squatter settlement makin merebak di berbagai sudut perkotaan di Indonesia, termasuk di Kota Semarang Metropolitan. Realita yang ada squatter settlement merebak menginvasi lahan-lahan kosong secara liar (illegal/tanpa hak milik) tanpa ijin kepada pemiliknya, lahan tidak terpelihara dan kurang (tidak ada) pengawasan dari pemilik lahan, akhirnya membentuk enclave-enclave kumuh.

Laju pertambahan penduduk (sumber daya manusia yang tidak mampu secara ekonomi atau minimnya pendapatan) yang makin pesat disetiap tahun merupakan salah satu faktor yang memicu perkembangan squatter settlement di beberapa tempat yang semestinya tidak diperkenankan untuk dijadikan sebagai kawasan permukiman.

Squatter settlement menyebar di berbagai lokasi di Kota Semarang, yakni di kawasan Urban Centre, Urban dan Sub Urban. Merebaknya squatter settlement tentu berkaitan erat dengan permasalahan sosial ekonomi masyarakat marginal, termasuk penyakit masyarakat (pathology social) yang berupa bentuk penyimpangan perilaku seperti kriminalitas dan vandalisme.

Squatter settlement tersebut dihuni oleh orang-orang yang berpenghasilan rendah (tidak mampu secara ekonomi). Lokasi squatter settlement berada di sekitar pasar tradisional, pemakaman umum, pasar tradisional, terminal lama, di bawah jembatan, dipinggir kali/sungai dan di jalur kereta api. Pada penelitian ini dipilih squatter settlement yang berada di jalur kereta api. Realita yang ada di jalur kereta api tampak bahwa telah terjadi konflik keruangan antara masyarakat dengan pengelola transportasi kereta api. Konflik tersebut berupa terjadinya pemanfaatan ruang (penyerobotan lahan milik PT Kereta Api Indonesia) menjadi kawasan squatter settlement pada jalur kereta api (koridor rel kereta api). Konflik pemanfaatan ruang yang terjadi di jalur kereta api, menggambarkan 
bahwa tidak adanya kontrol dan pengawasan yang ketat dari pihak berwenang (pemerintah).

\subsection{Rumusan Masalah}

- Terjadi konflik keruangan antara tempat tinggal dengan fungsi jalur kereta api.

- Merebaknya squatter settlement di jalur kereta api.

- Terjadi degradasi lingkungan pada jalur kereta api.

- kawasan rawan kecelakaan transportasi kereta api.

\subsection{Tujuan Penelitian}

Tujuan dari penelitian ini antara lain :

- Mengetahui konflik keruangan di jalur kereta api

- Memberikan gambaran tentang pemanfaatan ruang di jalur kereta api.

- Mengetahui kebijakan ruang pada jalur kereta api.

\subsection{Manfaat Penelitian}

Manfaat/kontribusi dari penelitian ini antara lain :

- Adanya suatu kajian yang dapat dimanfaatkan bagi pemerintah daerah, maupun semua pihak yang berkaitan dengan kawasan sepanjang jalur kereta api, dengan harapan pada kawasan tersebut pemanfaatan ruangnya dapat lebih terarah dan tertata dengan baik, memperhatikan dan mempertimbangkan kelestarian dan kualitas lingkungan hidup.

- Sebagai upaya penyiapan awal tentang pengelolaan ruang kawasan sepanjang jalur kereta api, dengan penuh pertimbangan dan tanggung jawab.

\subsection{Ruang Lingkup Substansial dan Spasial}

Ruang lingkup substansi penelitian ini adalah kondisi riil kondisi riil kehidupan orang-orang miskin di squatter settlement di jalur kereta api di Kota Semarang. Sedangkan ruang lingkup spasial penelitian ini adalah pada jalur kereta api antara Jl.BrotodjoyoJ1.Hasanudin, Kecamatan Semarang Tengah, Kota Semarang. Secara lebih jelas dapat dilihat pada gambar berikut. 


\section{LOKASI PENELITIAN SQUATTER SETTLEMENT BERADA DI SEBAGIAN KAMPUNG ABIMANYU, KELURAHAN PINDRIKAN LOR, KECAMATAN SEMARANG TENGAH KOTA SEMARANG}

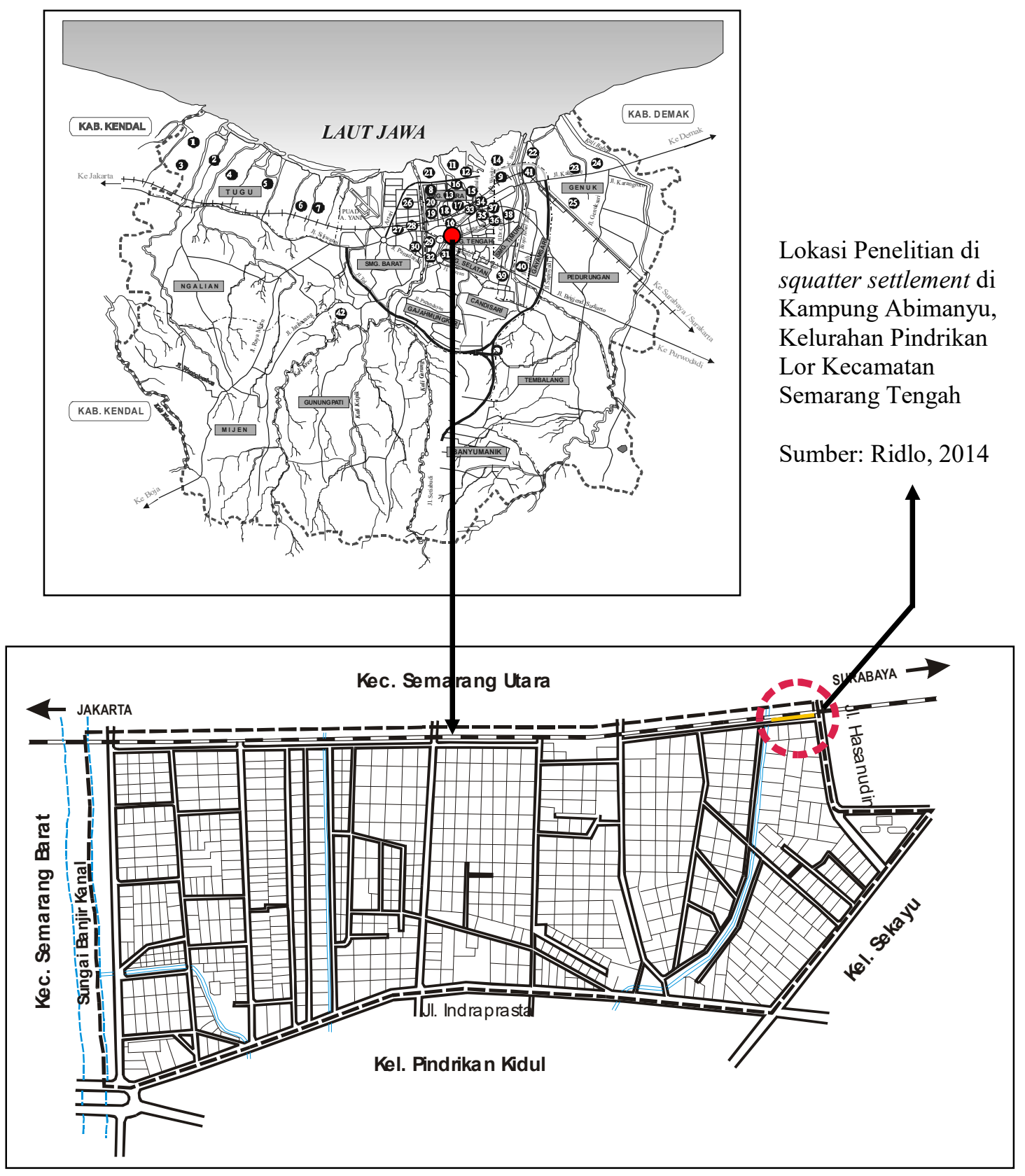

Gambar 1. Lokasi Penelitian di squatter settlement di Kampung Abimanyu, Kelurahan Pindrikan Lor Kecamatan Semarang Tengah

Sumber: Ridlo, 2014 
Jurnal Planologi Vol. 17 No. 2, Oktober 2020

Available : http://jurnal.unissula.ac.id/index.php/psa

\section{METODE PENELITIAN}

Penelitian ini dilakukan secara diskriptif kualitatif, melalui:

- Observasi empirik, interaktif, dengan metode induktif (dari sejumlah data) perilaku masyarakat yang dipelajari langsung dari habitat/lingkungannya, yang selanjutnya dianalisis berdasarkan kesesuaian antara teori dengan observasi yang ada di lapangan.

- Kajian teoritis, merupakan metode pendekatan yang dilakukan untuk membantu mengidentifikasi dan menganalisis dalam penelitian ini, tentunya yang berkaitan dengan permasalahan slum settlement and squatter settlement. Baik latar belakang terjadinya slum settlement and squatter settlement, standar suatu permukiman, strategi dan program-program yang telah dilakukan untuk mengatasi problem permukiman.

- Pendekatan dengan sistem keruangan untuk melihat lokasi slum settlement and squatter settlement dan aktivitas penduduknya.

\section{HASIL DAN PEMBAHASAN}

Dari hasil penelitian maka berikut ini disampaikan beberapa kajian yang berkaitan dengan tema penelitian yaitu kajian mengenai slum settlement and squatter settlement. Dalam UUD 1945 pasal $38 \mathrm{H}$ ayat (1) disebutkan bahwa setiap orang berhak hidup sejahtera lahir dan batin, bertempat tinggal, dan mendapatkan lingkungan hidup yang baik dan sehat serta berhak memperoleh pelayanan kesehatan. Menurut UU 1 tahun 2011 tentang Perumahan dan Kawasan Permukiman dijelaskan mengenai Hak dan Kewajiban Warga Negara dalam hal Perumahan. Hak dan kewajiban tersebut adalah (1) setiap warga negara mempunyai hak untuk menempati dan/atau menikmati dan / atau memiliki rumah yang layak dalam lingkungan yang sehat, aman, serasi, dan teratur; (2) Setiap warga negara mempunyai kewajiban dan tanggung jawab untuk berperan serta dalam pembangunan perumahan dan permukiman.

\subsection{Perumahan dan Permukiman}

Perumahan adalah kumpulan rumah sebagai bagian dari permukiman, baik perkotaan maupun perdesaan, yang dilengkapi dengan prasarana, sarana, dan utilitas umum sebagai hasil upaya pemenuhan rumah yang layak huni. Sementara permukiman adalah bagian dari lingkungan hunian yang terdiri atas lebih dari satu satuan perumahan yang mempunyai prasarana, sarana, utilitas umum, serta mempunyai penunjang kegiatan fungsi lain di kawasan perkotaan atau kawasan perdesaan (UU no.1 tahun 2011). Menurut Sumaatmadja permukiman adalah bagian permukaan bumi yang dihuni manusia meliputi 
segala sarana dan prasarana yang menunjang kehidupannya yang menjadi satu kesatuan dengan tempat tinggal yang bersangkutan (Sumaatmadja,1988).

Unsur-unsur utama pembentuk lingkungan permukiman menurut Doxiadis terdiri dari:

1. Alam (nature), Permukiman akan sangat ditentukan oleh adanya alam lingkungan (biotic maupun abiotic) seperti lingkungan hidup (flora dan fauna) maupun sumber daya fisik dasar (geologi dan pertambangan).

2. Manusia (antropos), Permukiman dipengaruhi oleh dinamika dan kinerja manusia.

3. Masyarakat (society), hakekatnya dibentuk karena adanya manusia sebagai kelompok masyarakat. Permukiman akan dipengaruhi oleh aspek-aspek dalam masyarakat antara lain seperti: kepadatan dan komposisi penduduk, pendidikan, kesehatan, ekonomi, stratifikasi sosial, struktur budaya, kesejahteraan dan hukum.

4. Ruang kehidupan (shell), manusia sebagai individu maupun sebagai kelompok masyarakat dalam melangsungkan kiprah kehidupannya dipastikan tidak terlepas adanya interaksi pada suatu ruang (spatial).

5. Jaringan (network), manusia dalam interaksi pada suatu ruang kehidupan perlu didukung adanya infrastruktur jaringan jalan, air bersih, drainase dan sewerage, listrik, telekomunikasi, dan sebagainya) (Doxiadis, 1974).

Dengan demikian bisa disimpulkan pengertian perumahan adalah kumpulan rumahrumah sebagai tempat bermukim manusia dalam melangsungkan kehidupannya, yang dapat memberi rasa aman, tenteram, nikmat, nyaman dan sejahtera, dalam keselarasan, keserasian dan keseimbangan agar berfungsi sebagai wadah yang dapat melayani kehidupan pribadi, keluarga maupun masyarakat. Sedangkan pengertian permukiman adalah suatu kawasan perumahan secara fungsional sebagai satuan sosial, ekonomi dan fisik ruang yang lengkap dengan prasarana lingkungan, prasarana dan sarana umum, dan fasilitas sosial yang mengandung keterpaduan kepentingan dan keselarasan pemanfaatan sebagai lingkungan kehidupan.

\subsection{Permukiman Kumuh dan Permukiman Liar}

Permukiman kumuh dan permukiman liar atau sering disebut dengan slum settlement dan squatter settlement, sebenarnya mudah dirasakan dan dilihat daripada dikatakan. Cukup sulit untuk membatasi apa sebenarnya yang dimaksud dengan permukiman kumuh dan liar itu. Gambaran kemiskinan akan selalu nampak jika kita melihat pemandangan dipermukiman kumuh dan permukiman liar, baik kemiskinan tempat maupun kemiskinan sosial. Kemiskinan tempat karena kondisinya sebagai tempat tinggal 
tidak manusiawi, berupa gubuk-gubuk tidak teratur, berdesak-desakan, terbuat dari barangbarang bekas seperti seng-seng bekas, plastik, karton, dan sisa-sisa buangan bangunan. Kadang-kadang tanah yang dipergunakan adalah liar tidak menurut rencana pemerintah, becek dan tidak memenuhi kesehatan seperti bawah jembatan, dipinggir kali/sungai, dipinggir rel KA, disekitar pasar, terminal-terminal lama, dan akhirnya membentuk perkampungan rapat yang padat dan berderet. Kemiskinan penduduk karena ditinjau dari segi sosial ekonomi kondisinya sangat rendah termasuk penyediaan air dan listrik beserta prasarana yang minim bahkan cenderung tidak tersedia. Kebanyakan penduduknya berpendidikan rendah, berstatus rendah, dan mempunyai struktur keluarga yang tidak menguntungkan. Permukiman tersebut merupakan tempat tinggal sebagian besar golongan berpenghasilan rendah (Cohen, 1976). Ia adalah tempat penduduk yang status sosial dan ekonominya rendah dan kondisi perumahan dibawah standar (Krausse, 1976). Demikianlah batasan permukiman kumuh dan liar menurut Krausse dan Cohen. Sedangkan Muhtar Lubis menggambarkan di gubuk-gubuk buruk dan kepingan papan, potongan bambu, beratap plastik dan berdinding karton, sosok wanita, lelaki dan anak-anak tidur berdesakan, dipinggir jalan KA, tidur diatas tanah yang hanya berlapis tikar sobek atau kertas koran tua dan plastik. Di sinilah manusia Indonesia hidup rendah diatas tanah, setiap hari benarbenar bergulat mencari sesuap nasi (Lubis M, 1977).

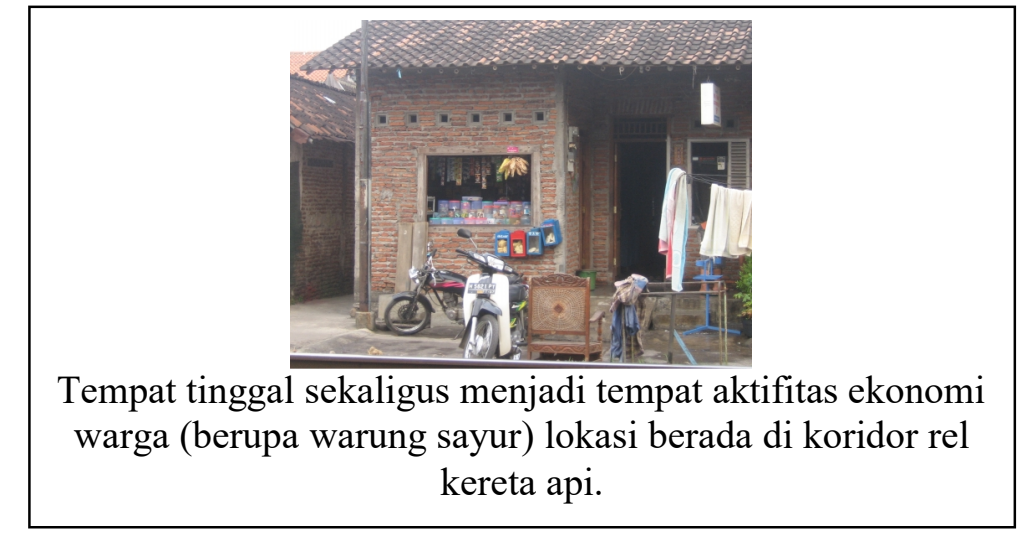

Gambar 2. Kondisi Aktifitas Ekonomi Di Koridor Rel

Menurut Huque, Asraf, 1975 menjelaskan permukiman kumuh sebagai terjemahan dari "marginal settlement" atau "shanty town" yang diberbagai negara memperoleh nama tersendiri seperti barriada (Peru), gececondu (Turki), buste (India), Chika (Ethiopia), bidonville (Afrika) dan sebagainya (Ridlo, 2001). 
Sedangkan Clerence Schubert 1979 dari United Nations Centre for Human Settlements (UNCHS) memberikan batasan tentang "marginal settlement" tersebut sebagai "primarily residential communities which are populated by low to middle income residents but which generally lock municipal infrastructure and social services and develop outside the formal urbanization process" (Ridlo, 2001).

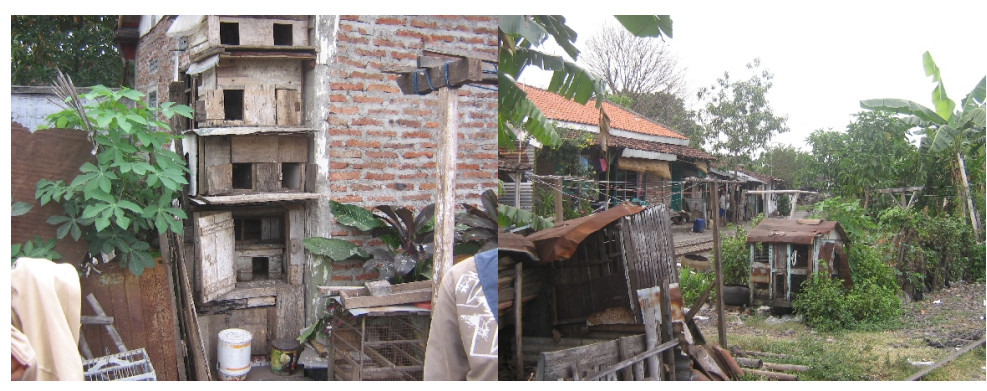

Kandang burung dan ayam berada $\pm 3 \mathrm{~m}$ dari rel kereta api. Letaknya dekat dengan tempat tinggalnya dan tidak menghiraukan nilai estetika, maupun nilai kesehatan.

Tampak sanitasi buruk tentu berdampak pada kesehatan warga di sekitarnya.

\section{Gambar 3. Gambar Aktifitas Lainnya di Sempadan Rel}

Dengan batasan semacam itu yang mengartikan "marginal settlement”sebagai lingkungan permukiman yang dihuni oleh kelompok masyarakat berpenghasilan rendah dan menengah akan tetapi yang kurang didukung oleh infrastruktur (Graham, Stephen, 2001), fasilitas dan pelayanan sosial dan berkembang di luar proses urbanisasi yang formal, maka tercakuplah dua kategori permukiman yang lazim disebut kumuh (slum) dan Liar (squatter).

Keduanya dengan ciri-ciri yang mirip tetapi pada hakekatnya berbeda, tidak bisa begitu saja di satukan dengan istilah permukiman kumuh. Cara penanganannyapun pastilah akan berlainan. Adapun batasan permukiman yang lazim disebut kumuh (slum settlement) dan Liar (squatter settlement) sebagai berikut:

- Slum settlement adalah suatu kawasan (bisa disebut dengan kampung) yang terdiri dari beberapa rumah dengan kondisi kumuh, kurang layak huni dengan kepadatan tinggi, umur bangunannya sudah menua; kepemilikan lahannya absah atau legal; kurang tersedianya sarana dan prasarana lingkungan (fasilitas publik); fisik kawasannya buruk dan kurang terpelihara. Slum settlement ini merupakan potret yang mencerminkan wujud adanya kemiskinan di perkotaan. Beberapa kampung kumuh (Slum settlement) di perkotaan di Indonesia telah memperoleh Program Perbaikan 
Kampung (PPK) atau Kampong Improvement Programme (KIP) berubah menjadi lingkungan permukiman yang layak huni (Jellinek, Lea, 1995).

- Squatter settlement adalah suatu kawasan yang terdiri dari beberapa rumah dengan kondisi kumuh, kurang layak huni dengan kepadatan tinggi, berada di lahan milih orang lain atau milik pemerintah (kepemilikan lahannya tidak absah, liar atau illegal); tidak tersedianya sarana dan prasarana lingkungan (fasilitas publik); fisik kawasannya buruk dan kurang terpelihara. Yang dimaksud dengan lahan illegal adalah antara lain lahan kuburan, tempat pembuangan sampah, tanggul dan bantaran sungai, dibalik dinding tembok milik orang lain, sepanjang tepi rel kereta api, di bawah jembatan, dan lain-lain (Ridlo, 2001).

Dari uraian diatas dapat disimpulkan bahwa permukiman kumuh (slum settlement) dan permukiman liar (squatter settlement) adalah kawasan yang dipergunakan sebagai tempat tinggal. Kondisi sosial dan ekonomi penduduknya rendah, penghasilan dibawah standar, dan merupakan kantong-kantong (enclave-enclave) kemiskinan perkotaan.

Karakteristik dari permukiman kumuh (slum settlement) antara lain:

- Lingkungan fisiknya dengan kondisi buruk dan kurang sehat.

- Tidak/kurang tersedia sarana dan prasarana umum yang layak dan memadai untuk penduduk.

- Bangunan tempat tinggal (rumah) dengan tata letak yang tidak teratur, kondisinya rapat dan padat.

- Lahan yang ditempati merupakan lahan miliknya sendiri yang berarti absah atau legal.

- Bangunan tempat tinggal sudah menua, karena ketidakacuhan sehingga kurang terpelihara, disamping faktor ekonomi penduduk kurang mendukung.

- Sejalan dengan pertambahan jumlah penghuni, maka bangunan tempat tinggal dibagibagi menjadi petak-petak ruang bangunan yang semakin kecil dan padat penghuni.

Sedangkan karakteristik dari permukiman liar (squatter settlement) antara lain:

- Lingkungan fisiknya dengan kondisi buruk dan kurang sehat.

- Tidak tersedia sarana dan prasarana umum untuk penduduk.

- Bangunan tempat tinggal (rumah) dengan tata letak yang tidak teratur, kondisinya rapat dan padat.

- Squatter settlement menempati lahan milik orang lain, swasta atau milik pemerintah, yang berarti tidak absah atau illegal. 
- Squatter settlement lepas dari pengawasan (tidak terkontrol) pemilik lahan (swasta maupun pemerintah), dengan kata lain squatter settlement terkesan adanya pembiaran oleh yang berwenang.

- Lokasi squatter settlement berada di sekitar pasar tradisional, pemakaman umum, pasar tradisional, terminal laman, di bawah jembatan, dipinggir kali/sungai dan di jalur kereta api.

- Kondisi fisik lingkungan dan

- Bahan bangunan yang dipakai berupa sisa-sia bongkaran bangunan seperti kayu, papan dan seng bekas, kardus/karton, spanduk (MMT) bekas dan bahan lain yang bersifat semi permanen.

- Lokasi squatter settlement tidak sesuai dengan peruntukan kawasan (peraturan rencana tata ruang) dan peraturan perundang-undangan lainnya.

Ke semua itu pada akhirnya akan membentuk suatu perkampungan rapat yang sangat padat dan berderet, tanpa sarana dan prasarana yang memadai.

Lingkungan permukiman kumuh dan liar di perkotaan sebagian besar merupakan permukiman yang kehadirannya tidak terencana atau sesuai dengan rencana kota. Pembangunan permukiman di perkotaan melibatkan berbagai aktor pembangunan yaitu: pemerintah, swasta dan masyarakat.

\subsection{Squatter Settlement di Kota Semarang}

Permasalahan squatter settlement di Kota Semarang muncul karena pemukimnya para "migran" dan "urbanis" memerlukan tempat tinggal sebagai tempat berteduh (shelter) sementara. Mereka melepas penat setelah seharian bekerja (sebagian besar di sektor informal). Hal tersebut berlangsung terus menerus tanpa pengawasan oleh pemerintah (terkesan adanya pembiaran), semakin lama bertambah jumlah penduduknya dan akhirnya squatter settlement semakin merebak dan padat (Ridlo, 2020).

Melihat realita di Kota Semarang, terdapat issue strategis yang berkaitan dengan masalah squatter settlement, antara lain:

- Faktor migrasi (baca: urbanisasi) penduduk yaitu terjadinya pergeseran atau perpindahan penduduk dari satu tempat ke tempat lain (Gilbert, A \& Gugler, J, 1996).

- Faktor lahan perkotaan yaitu terjadinya invasi lahan perkotaan oleh penduduk, seperti pada lahan di jalur rel kereta api, koridor sungai/kali, area pemakaman, tempat pembuangan akhir sampah, dana lahan lahan kosong yang tidak diawasi oleh pemiliknya. 
- Pertumbuhan penduduk yang berdampak pada kebutuhan lahan sebagai tempat tinggal dan beberapa diantaranya tumbuh menjadi permukiman illegal atau sering disebut dengan Squatter settlement yang tidak teratur dan padat (Ridlo, 2011).

Squatter settlement di Kota Semarang tersebar di berbagai sudut (enclave-enclave) kota. Berdasarkan sistem keruangan, penyebaran permukiman kumuh dikelompokkan menjadi 3 (tiga) kawasan keruangan (spatial area), yakni kawasan Urban Centre, Urban dan Sub Urban. Sistem keruangan yang dimaksud adalah pola penggunaan lahan pada suatu kawasan (area) yang berhubungan dengan aktivitas masyarakatnya. Dengan kata lain bahwa sistem keruangan diinterpretasikan dalam circum aktivitas yang tampak (Sesuai dengan permintakatan atau zoningnya), baik secara ekonomi seperti: perdagangan, perkantoran, industri, pertokoan, perdagangan dan lain-lain.

Tabel 1. Squatter Settlement Sesuai Dengan Permintakatan dan Zoning Di Kota Semarang

\begin{tabular}{|c|c|c|c|c|}
\hline No & Mintakat & Urban Centre & Urban & Sub Urban \\
\hline 1. & $\begin{array}{ll}\text { Pergudangan, } & \\
\text { Transportasi } \\
\text { dan Pelabuhan }\end{array}$ & $\begin{array}{ll}\text { Kampung } & \text { Melayu/ } \\
\text { Jawa/Arab } & \end{array}$ & $\begin{array}{l}\text { Plombokan,Tawang, } \\
\text { Tawangmas, } \\
\text { Kebonhardjo, } \\
\text { Dadapsari, Kuningan, } \\
\text { Purwosari, } \\
\text { Tanjungmas, } \\
\text { Bandarhardjo, } \\
\text { Panggung Kidul, } \\
\text { Panggung Lor }\end{array}$ & Tambakrejo \\
\hline 2. & Perkantoran & - & $\begin{array}{l}\text { Bojong Salaman, } \\
\text { Sleko,Sayangan }\end{array}$ & - \\
\hline 3. & $\begin{array}{l}\text { Industri, } \\
\text { Transportasi }\end{array}$ & - & - & $\begin{array}{l}\text { Tugurejo, Jrakah, } \\
\text { Terboyo Kulon, } \\
\text { Terboyo } \\
\text { Wetan,Trimulyo, } \\
\text { Genuksari }\end{array}$ \\
\hline 4. & $\begin{array}{l}\text { Pantai (nelayan, } \\
\text { Tambak) }\end{array}$ & - & - & $\begin{array}{ll}\text { Mangunharjo, } \\
\text { Mangkang } \\
\text { Mangkang } & \text { Kulon, } \\
\text { Randugarut, } & \\
\text { Karanganyar } & \\
\end{array}$ \\
\hline 5. & Makam/ Kuburan & Kalisari & Kobong & - \\
\hline 6. & $\begin{array}{l}\text { Perdagangan, } \\
\text { Pertokoan, Pasar. }\end{array}$ & $\begin{array}{l}\text { Pekojan, } \\
\text { Purwodinatan } \\
\text { (Sumeneban), Lemah } \\
\text { Gempal, } \\
\text { Banjirkanal,Bulu, } \\
\text { Bulu Lor, Karang } \\
\text { Ayu }\end{array}$ & $\begin{array}{l}\text { Krakasan, Bubakan, } \\
\text { Dargo, Peterongan, } \\
\text { Pandean Lamper }\end{array}$ & - \\
\hline 7. & Pertanian & - & - & Sukorejo \\
\hline
\end{tabular}

Sumber: Ridlo, Mohammad Agung; Sugiono Soetomo; Nurdien H Kistanto, 2014. 
Jurnal Planologi Vol. 17 No. 2, Oktober 2020 Available : http://jurnal.unissula.ac.id/index.php/psa
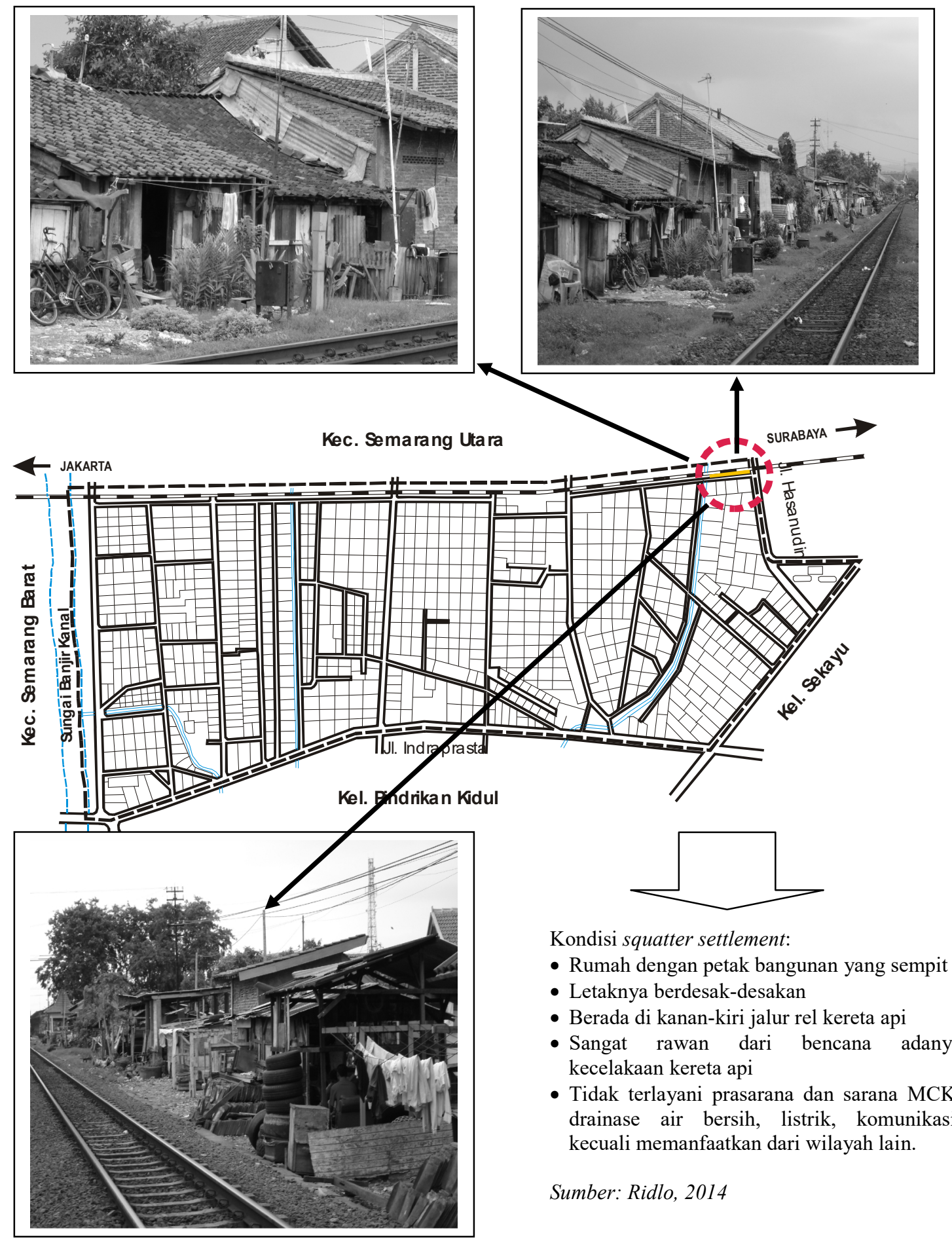

Gambar 4. Kondisi Squatter Settlement di Kampung Abimanyu Kelurahan Pindrikan Lor, Kecamatan Semarang Tengah, Kota Semarang 
Jurnal Planologi Vol. 17 No. 2, Oktober 2020

Available : http://jurnal.unissula.ac.id/index.php/psa

\subsection{Squatter Settlement di jalur kereta api}

Khusus pada kajian ini adalah squatter settlement yang berada di jalur kereta api. Squatter settlement mempunyai kondisi eksisting seperti: rawan banjir, kebakaran, prasarana tidak memadai, sanitasi lingkungan buruk, tidak ada sumber air bersih, tempat tinggal atau hunian yang tidak/kurang layak, serta padat penduduk (Ridlo, 2014).

Kondisi eksisting kehadiran pemukim squatter di jalur kereta api di Kota Semarang seperti:

Pertama, Warga secara sendiri-sendiri menginvasi lahan (menetap di atas lahan) yang mereka anggap tidak ditempati dengan atau tanpa izin kepada yang memiliki (dalam hal ini PT. KAI).

Kedua, Squatter settlement yang didasarkan pada transaksi non resmi, yaitu warga awalnya membangun tempat tinggal seadanya diatas lahan dengan membayar uang sewa pada petugas PT KAI, namun sudah lama tidak ditarik lagi uang sewanya. Kemudian terdapat jual beli tempat tinggal di sebidang lahan dari seorang penjual yang mengatakan menguasai lahan tersebut atau yang sebenarnya tidak mempunyai hak, baik untuk memiliki atau menjual lahan tersebut kepada siapa pun.

Kondisi ekonomi penduduk seperti: berpenghasilan rendah dan sangat rendah, tingkat pengangguran tinggi, kondisi sosial rendah (tingkat pendidikan dan kesehatan rendah serta sumber kriminalitas), kondisi aspek hukum (hunian illegal, tidak sesuai dengan ketentuan dan peraturan).

Jalur kereta api seharusnya menjadi lahan bebas dari permukiman, mengingat lahan tersebut ditetapkan sebagai ruang milik jalur kereta api. Penetapan ruang milik jalur kereta api selain menyangkut keselamatan bagi transportasi kereta api juga menyangkut keselamatan penduduk yang wilayah nya terlintasi oleh jaringan rel kereta api.

Menurut Undang-Undang Nomor 23 Tahun 2007 tentang Perkeretaapian. Pada pasal 42 menyebutkan bahwa ruang milik jalur kereta api adalah bidang tanah di kiri dan di kanan ruang manfaat jalur kereta api yang digunakan untuk pengamanan konstruksi jalan rel. Lebih lanjut pasal 43 menyebutkan: ruang milik jalur kereta api diluar ruang manfaat jalur kereta api dapat dimanfaatkan untuk keperluan lain atas izin dari pemilik jalur dengan tidak membahayakan konstruksi jalan rel dan fasilitas operasi kereta api. Selain ruang manfaat rel kereta api dan ruang milik jalur kereta api terdapat juga ruang pengawasan jalur kereta api. Definisi ruang pengawasan jalur kereta api menurut terdapat pada pasal 44 yang menyebutkan bahwa "ruang pengawasan jalur kereta api adalah 
bidang tanah atau bidang lain di kiri dan di kanan ruang milik jalur kereta api untuk pengamanan dan kelancaran operasi kereta api”.

Diantara ke tiga fungsi ruang rel kereta api diatas, ruang manfaat kereta api lah yang tidak diperuntukkan untuk umum mengingat berfungsi sebagai pengoperasian kereta api (Pasal 38). Ruang milik jalur kereta api biasanya di lapangan di tandai dengan tanda batas tertentu (berupa patok besi).

Kemudian pada Pasal 178 UU Perkeretaapian, bahwa setiap orang dilarang membangun gedung, membuat tembok, pagar, tanggul, bangunan lainnya, menanam jenis pohon yang tinggi, atau menempatkan barang pada jalur kereta api yang dapat mengganggu pandangan bebas dan membahayakan keselamatan perjalanan kereta api.

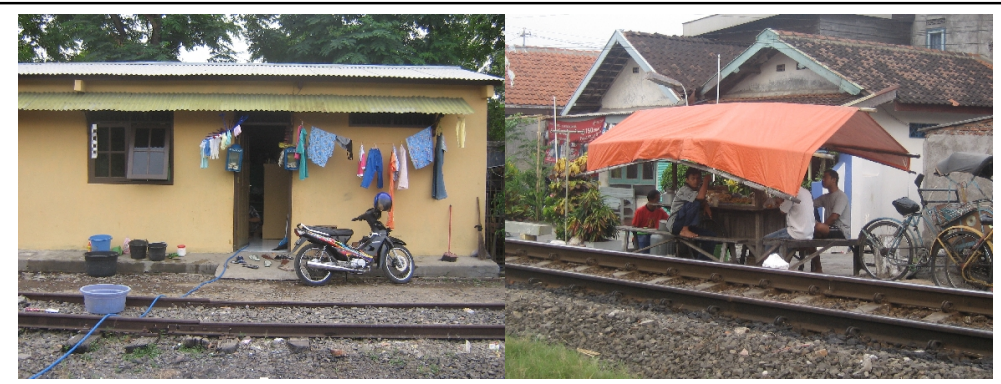

Warung sembako dan PKL(gerobak kucingan)tepat disisi rel kereta api, jaraknya

$\pm 1 \mathrm{~m}$ dari badan kereta api saat lewat. Sangat rawan kecelakaan, mengingat jaraknya yang terlalu dekat dengan rel kereta api.

Gambar 5. Warung sembako dan PKL(gerobak kucingan)

Squatter settlement di jalur kereta api di Kota Semarang kondisinya sangat memprihatinkan. Lokasi bangunan tempat tinggal dan aktivitasnya sangat mepet ke ruang manfaat rel kereta api. Kondisi eksisting permukiman warga yang berupa squatter settlement dibangun sangat dekat dengan jalur rel kereta api, yaitu sekitar $3 \mathrm{~m}$.

Hal ini sangat mengganggu dan membahayakan sirkulasi moda transportasi kereta api, tentunya ini menjadi ancaman terjadinya musibah kecelakaan, karena bangunanbangunan yang ada konstruksinya mengganggu operasional pengawasan kereta api. Jika terjadi musibah kecelakaan pastinya yang menjadi korban tidak hanya pengguna moda kereta api saja, tetapi juga penduduk yang ada di jalur kereta api tersebut.

Dengan kata lain bahwa, sampai saat ini aset-aset PT KAI yang berupa lahan tampaknya tidak terkelola dengan baik. Buktinya kawasan jalur kereta api yang menjadi 
Jurnal Planologi Vol. 17 No. 2, Oktober 2020

kewenangannya tampak sebagian besar dimanfaatkan oleh penduduk sebagai permukiman yang kondisinya rapat, padat dan kumuh.

Kondisi eksisting tersebut tentu menyalahi peraturan Aanvullende Bepalingen Spooren Tramwegen (A.B.S.T). Pada pasal 21 A.B.S.T mengatur mengenai pelarangan mendirikan berbagai bangunan maupun menanam tumbuhan atau vegetasi di jalur kereta api yang dapat mengganggu sirkulasi moda transportasi kereta api.

A.B.S.T mengatur jarak minimal diperbolehkan adanya tanaman atau vegetasi adalah 11 meter diukur dari sumbu jalan jalan baja (rel kereta api). Sedangkan diperbolehkan adanya berbagai bangunan adalah 20 meter diukur dari sumbu jalan jalan baja (rel kereta api), jika jalur kereta api (jalan baja) dalam posisi lurus. Kemudian jika jalur kereta api (jalan baja) dalam posisi berbelok, maka jarak yang terletak di lengkungan diperkenankan minimal 23 meter meter diukur dari sumbu jalan jalan baja (rel kereta api) (Sumber: Keputusan Direktur Jendral Perkeretaapian dan Menteri Perhubungan, 2000:21).

Area Jalur kereta api meliputi: ruang milik jalan (rumaja) kereta api, ruang milik jalan (rumija) kereta api dan ruang pengawasan jalan (ruwasja) kereta api. Bantaran rel kereta api merupakan garis batas luar ruang pengawasan jalan (ruwasja) kereta api. Sehingga area jalur kereta api tersebut merupakan area (ruang) bebas yang tidak diperkenankan adanya bangunan. Dengan kata lain bahwa area (ruang) bebas jalur kereta api adalah ruang yang tidak diperkenankan adanya aktivitas yang dapat menganggu gerakan dan sirkulasi kereta api, dengan maksud agar kereta api berjalan dengan lancar dan aman. (Keputusan Menteri Perhubungan Nomor: KM 52 tahun 2000 Pasal 1 ayat 3 dan 7).

Realita eksiting squatter settlement di kanan-kiri jalur kereta api antara lain seperti:

- Tidak layak huni, walaupun ada beberapa yang dibangun dengan menggunakan bahan yang permanen (batu bata atau setengah batu bata) pada petak sisa lahan dengan ukuran kecil.

- Permukiman tersebut juga tidak tersedia saluran sanitasi dan MCK yang baik. Setiap kali ingin membuang hajat mereka harus numpang di tetangga yang mempunyai MCK, ke MCK umum, ke sungai-sungai atau drainase yang ada di sekitar lokasi.

- Letak bangunan yang berhimpitan, dengan kondisi lingkungan yang buruk

- Squatter settlement tersebut sangat tidak memperhatikan faktor keamanan, karena jarak permukiman dengan jalur rel kereta api Jakarta-Surabaya sangat dekat, yaitu berjarak \pm 3 meter, sehingga apabila terjadi kecelakaan kereta api di dekatnya tentulah permukiman tersebut langsung terkena dampak dari kecelakaan. 


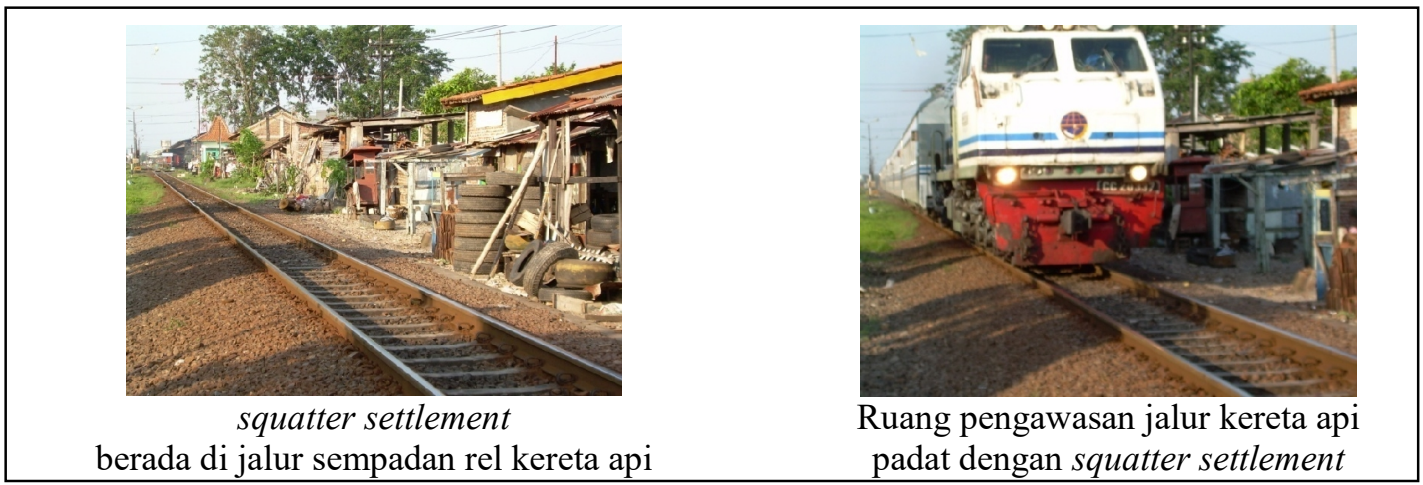

Gambar 6. Squatter settlement di sempadan rel

Kondisi rumah kumuh illegal di koridor rel kereta api dengan kondisi sangat tidak layak huni. Letak rumah sangat dekat dengan rel kereta api, yang seharusnya kawasan ini tidak diperkenankan didirikan bangunan,

karena rentan terhadap bahaya kecelakaan.

Gambar 7. Kondisi rumah kuuh ilegal

\section{KESIMPULAN}

Dari hasil penelitian mengenai kehidupan orang orang miskin di squatter settlement yang berada di jalur kereta api Kota Semarang, maka dapat disimpulkan antara lain:

- Dilihat dari perspektif keruangan dan berupaya memahami realitas yang terjadi di balik keberadaan squatter settlement di jalur kereta api, maka terdapat keterkaitan (aksesibilitas/jaringan) antara manusia dengan lingkungannya (sebagai wadah) serta aktivitas yang dilakukan (baik dalam aspek fisik, sosial, ekonomi maupun politik) di keruangan kota.

- Squatter settlement merupakan tempat tinggal orang-orang miskin di kota, dengan berbagai keterbatasan secara fisik bangunan dan lingkungan, aspek sosial maupun aspek ekonomi.

- Squatter settlement merupakan tempat tinggal sementara bagi mereka dalam membangun kehidupan dan mata pencaharian. Lokasi tersebut dipilih karena 
berdekatan dengan lokasi (tempat) mereka bekerja atau beraktivitas ekonomi kesehariaan.

- Squatter settlement merupakan salah satu kebutuhan dasar manusia yang berupa tempat tinggal (hunian atau shelter) yang berfungsi sebagai tempat beristirahat.dan berlindung dari berbagai gangguan seperti: cuaca panas, dingin, hujan dan terpaan angin. Selain itu juga berfungsi sebagai tempat beraktivitas ekonomi bagi penghuninya, juga sebagai tempat untuk kegiatan yang bersifat pribadi.

- Setiap individu mempunyai hak untuk pemenuhan kebutuhan tempat tinggal. Demikian pula halnya orang orang miskin di perkotaan, perlu mendapat perhatian dari pemerintah dalam mencukupi kebutuhan tempat tinggal yang layak bagi mereka.

- Squatter settlement ada karena mereka (orang-orang miskin) menghadapi berbagai kendala dan keterbatasan dalam mendapatkan perumahan yang layak. Kendala dan keterbatasan tersebut antara lain seperti: administrasi dan birokrasi yang rumit, ketersediaan waktu, dan ketidakmampuan keuangan. Oleh karena itu squatter settlement adalah alternatif bagi mereka sebagai tempat tinggal; dan itu merupakan fakta riil yang tidak dapat dipungkiri.

- Squatter settlement merupakan bentuk penguasaan dan penggunaan lahan oleh warga, hal tersebut menggambarkan bahwa lemahnya sisi hukum dan administrasi dari pemerintah setempat dalam pengawasan suatu lahan ruang kota.

- Jalur rel kereta menjadi salah satu pilihan para urbanis (dengan segala keterbatasannya) membangun rumah sebagai tempat tinggal (squatter settlement).

- Tempat tinggal yang layak akan menentukan taraf hidup masyarakat.

- Konflik pemanfaatan ruang yang terjadi di jalur kereta api, menggambarkan bahwa tidak adanya kontrol dan pengawasan yang ketat dari pihak berwenang (pemerintah). Mestinya pemerintah dapat melihat peraturan pemanfaatan ruang (dokumen rencana tata ruang) maupun peraturan lain yang terkait, sehingga jika terdapat penyimpangan pemanfaatan ruang dapat melakukan penanganan segera sejak dini.

\section{Ucapan Terima Kasih}

Melalui tulisan ini penulis mengucapkan terima kasih kepada Bapak Rektor Universitas Islam Sultan Agung (UNISSULA) yang telah mendanai penelitian ini. Kemudian penulis juga tidak lupa sampaikan terima kasih pula kepada Ketua Lembaga 
Jurnal Planologi Vol. 17 No. 2, Oktober 2020

Available : http://jurnal.unissula.ac.id/index.php/psa

Penelitian dan Pengembangan Ilmu (LPPM) UNISSULA dan Dekan Fakultas Teknik UNISSULA yang telah memfasilitasi penelitian ini.

\section{DAFTAR PUSTAKA}

Cohen, M. (1976). Canda and the United States: Dispute Settlement and the International Joint Commission--Can This Experience be Applied to Law of the Sea Issues. Case W. Res. J. Int'l L., 8, 69 .

Dieters, Hans Dan Rudiger Korff (2002). Urbanisme Di Asia Tenggara, Terjemahan Zulfahmi, Yayasan Obor Indonesia, Jakarta

Doxiadis, C. (1974). Ecumenopolis: The Inevitable City of the Future, W.W Norton \& Company, New York.

Gilbert, A., \& Gugler, J. (1996). Urbanisasi dan kemiskinan di dunia ketiga. Tiara Wacana Yogya.

Graham, S., \& Marvin, S. (2001). Splintering urbanism: networked infrastructures, technological mobilities and the urban condition. Psychology Press.

Krausse, G. (1976) "Rural-Urban Migration to Jakarta, Indonesia”, Proceedings of the Canadian Association of Geographers, 74-76. Laval University, Quebec City, Quebec

Lubis, Mochtar. (1977). Jakarta Kota yang Penuh dengan Kontras, Prisma

Sumaatmadja, Nursyid. (1988). Studi Geografi Suatu pendekatan dan Analisa Geografi. Bandung: Alumni

Jellinek, Lea. (1995) Seperti Roda Berputar, Perubahan Sosial Sebuah Kampung Di Jakarta, Terjemahan Eddy Zainuri, Penerbit LP3ES, Jakarta

Ridlo, M. A., Soetomo, S., \& Kistanto, N. H. Theoretical Study Of Poverty In Urban Slum Settlements, Journal of Scientific \& Technology Research, 9 (3), 4825-4829.

Ridlo, M. A., Soetomo, S., \& Kistanto, N. H. The Phenomenon Of Life Of The Poor In City Slums. International Journal of Business Economics and Law (IJBEL), 5 (4). 124-130

Ridlo, M. A., Soetomo, S., \& Kistanto, N. H. (2014). The Life Pattern Of The Poor Society In Semarang City-Indonesia State. International Journal of Business Economics and Law (IJBEL), 4 (3), 25-35.

Ridlo, M. A., (2011) Perumahan dan Permukiman di Perkotaan - Fakta, Anaisis dan Solusi, Cetakan Pertama, UNISSULA PRESS.

Ridlo, M. A., (2001). Kemiskinan di Perkotaan, Cetakan Pertama, UNISSULA PRESS.

Undang-Undang Nomor 1 tahun 2011 tentang Perumahan dan Kawasan Permukiman 